\title{
City Logistics Between International Vision and Local Knowledge to Sustainable Development: The Regional Role on Planning and on Public Engagement
}

\author{
Francesco Russo $^{1 *}$, Tommaso Calabrò ${ }^{2}$, Giuseppe Iiritano ${ }^{2}$, Domenica Savia Pellicanò ${ }^{1}$, Giovanna Petrungaro ${ }^{2}$, \\ Maria Rosaria Trecozzi ${ }^{2}$ \\ ${ }^{1}$ Dipartimento di Ingegneria dell'Informazione, delle Infrastrutture e dell'Energia Sostenibile, Università degli Studi \\ Mediterranea di Reggio Calabria, Reggio Calabria 89124, Italy \\ ${ }^{2}$ Dipartimento Lavori Pubblici, Public Administration of Regione Calabria, Catanzaro 88100, Italy
}

Corresponding Author Email: francesco.russo@unirc.it

https://doi.org/10.18280/ijsdp.150504

Received: 31 December 2019

Accepted: 15 May 2020

\section{Keywords:}

urban freight transport, city logistics, public engagement, sustainable development, SUMP, regional plan, urban development, sustainability, smart city

\begin{abstract}
The sustainable development is a main goal of Calabria Region that has promoted a lot of activities to contrast climate change in line with international, European and national targets. In the field of city logistics, the Region can operate only through moral and financial support; a technical and administrative process has been developed including the definition of planning, programming and implementation processes on a regional scale. The realization of city logistics in the Calabria urban centers was planned starting from the Regional Transport Plan (RTP) in 2016, programmed through the Implementation Program in 2017, implemented by a first Call published in the 2018 and a second Call in 2019. The city logistics process has been supported by a structured public engagement through training activities according to the National Coordination Center for Public Engagement (NCCPE) and the Evaluation Program and United States National Security Exercise (HSEEP), adequately specified. Calabria Region policy is oriented to achieve a process of participation and sharing of choices raising the levels of knowledge on the urban freight transport and the sustainability development of cities. The objective is to create an urban logistics with zero $\mathrm{CO}_{2}$ emissions by 2030 according to sustainability targets set at international, European, national level.
\end{abstract}

\section{INTRODUCTION}

Environment, economy and society are the three fundamental components of sustainable development introduced in 1987 in the Our Common Future report, better known as the Brundtland Report [1].

There are several definitions of sustainable development given at different public level from international to local scale. Any coordination and/or any prescription go from one level to another.

In 2015, some key agreements were signed by governments around the world. On one side, the 2030 Agenda of United Nations (UN) aimed at building a strategic framework of the Sustainable Development Goals (SDGs) quantitatively defined by targets and indicators [2]. On the other side, the Paris Agreement of the Framework Convention on Climate Change (UNFCCC), aimed to contain terrestrial heating below $2^{\circ} \mathrm{C}$, compared to pre-industrial levels, by a significantly reducing $\mathrm{CO}_{2}$ emissions against climate change [3].

Urban areas contribute with about $23 \%$ to all $\mathrm{CO}_{2}$ emissions produced by transport. Cities need to make more efforts to turn past trends around and contribute to achieving the $60 \%$ reduction in greenhouse gas emissions called for by the White Paper on transport [4]

In the components of the transport, the urban freight transport has played an important role in the field of sustainability in recent years. It is a main part of the supply chain; provides an essential service for both commercial activities and final consumers, but it has negative externalities on sustainability development in environmental terms, as well as on economic and social terms [5-7].

In cities is complex to move towards a low-carbon transport than the transport system as a whole, but there is a greater potential of several measures such as walking, cycling, public transport and the early market introduction of vehicles powered by alternative fuels.

It is important to note that the drastic reduction of vehicles to reduce $\mathrm{CO}_{2}$ emissions is not a solution. Cities could empty because they would be less commercial attractiveness or residential and working activities. So, should be found a tradeoff between $\mathrm{CO}_{2}$ reduction and economic development, also improving accessibility.

Public administrations can promote different actions developed with the objective of sustainable development. For instance, some actions may be programs to develop collective transport, strengthening and renewal of fleets of public transport vehicles and specific programs related to urban logistics.

The challenge is to be able to pursue the great sustainability target at a global level and to achieve the development of sustainability in the cities.

The role of regional administration in Italy is very different respect to field of interventions at urban level. In public transit system, the regional administration is the main decision maker because organize the regional collective transport plan and finance about the $70 \%$ of the cost that for the over $30 \%$ is 
covered by the tickets. Very different is the case of the freight transport in the city. In this case, the regional administration has any role and then can assume, if it wants, only a moral suasion role.

Moreover, the regional administrations can play an effective role in accompanying local administrations to realize the projects because they can orient and support them with the implementation of the best scientific knowledge.

Calabria regional administration has activated a technical, administrative and mainly financial path to pursue sustainability through city logistics measures.

City logistics is an effective tool to reduce the impacts of freight transport by measures implementation. There is a wide range of city logistics measures that can be grouped into different categories $[8,9]$ :

- $\quad$ supply and/or demand management;

- infrastructural actions;

- ICT and ITS application;

- environment-friendly vehicle;

- support for public-private collaboration,

- reverse logistics.

City logistics is an effective tool to increase sustainability and liveability [10-12] on city linked to reduction of heavy impacts generated by number of deliveries and vehicles in residential areas. To equilibrate the prescriptive top down planning process, the Region asks to activate with/in the cities a public engagement process.

Public engagement (PE) is an effective tool to support local administration in a general framework of the participatory approach to improve capability on specific item. PE operates as a balancing bottom up process.

Then, local and regional administrations can have a key role, but very different, in the implementation of global agreements. They can to pursue the development of sustainability by actions to reach the great sustainability target from global to local level. These actions can be policies, strategies, programs to realize interventions [13].

In particular, a public administration, as Region, can be of support to the other public administration, as city, in the link from his actions for development of sustainability to realization. Financial grant and PE are the means that can be activated. PE can include outreach, collaborative research, citizen science, lifelong learning, community engagement, and engagement with partners.

In Calabria, there are some cities that already show attention to sustainability and have started drawing up plans for urban mobility, including city logistics. For example, Reggio Calabria has approved the proposal of the PUMS, Catanzaro is preparing it.

Respect to urban sustainability problems, the paper has been elaborated to answer some questions that can be summarized as follows.

There are several international and national documents that represent a reference framework that includes general indicators to measure sustainability and assess the level of achievement respect to the set targets. How is it possible to translate these documents to have a qualitative direction and to give to local administrations quantitative specific indicators and targets to pursue the sustainability?

Section 2 answers this question and reports a summary of the sustainability goals set at different territorial scales, from international to regional levels. The indicators and the targets proposed by each level are also reported and compared.
City logistics plays an important role for sustainability especially as regards the reduction of the impacts of freight vehicles in urban areas on environment, economic development and accessibility, How is it possible to build an innovative tool to be used by regional administrations to solve the freight transport problem, based on top down path, and considering that there are no references as the technical standards of construction (TSC)?

Section 3 answers this question and illustrates a model to simulate urban freight transport that can be considered as a specific guideline, a reference technical standard for city logistics.

The proposed freight traffic solution is innovative. Local administrations not have complete knowledge to deal with the problem of city logistics. How it is possible to insert a bottom up path to increase their knowledge and to involve them in the regional decisions for the success of the initiative?

Section 4 answers this question and illustrates the PE realized that includes the application of the proposed model to a real case.

\section{SUSTAINABLE DEVELOPMENT: FROM QUALITATIVE VISION TO QUANTITATIVE INDICATORS}

Sustainable development is the development that meets the needs of the present without compromising the ability of future generations to meet their own needs [1]. It can be defined through its three main components: economy, society and environment; three important and independent sectors that are closely linked in the field of sustainability [14].

Sustainable development is the focus of policies and strategies adopted at international, European, national and regional level.

In 2015 , UN affirmed the main principles of sustainability by strengthening and integrating them into a program of action: Transforming our world: the 2030 Global Agenda for Sustainable Development [15]. This document has 17 Sustainable Development Goals (SDGs), 169 targets and 244 indicators [2].

City logistics is a theme of the goal 11Make cities and human settlements inclusive, safe, resilient and sustainable and the related target is 11.6 By 2030, reduce the adverse per capita environmental impact of cities, including by paying special attention to air quality and municipal and other waste management. The specific measurable indicator is 11.6.2 Annual mean levels of fine particulate matter (e.g. PM2.5 and PM10) in cities (population weighted).

In 2019, the European Commission proposed a document in which the sustainability and the climate sector are specific challenges [16]. The environmental theme is deepened in the Policy Objective 2: A low carbon and greener Europe - Clean and fair energy transition, green and blue investment, circular economy, climate adaptation and risk prevention.

It is possible to assume that the targets relating to the climate change are:

- $\quad$ promote energy efficiency and the renewable energies;

- $\quad$ adaptation to climate change;

The related indicators are:

- number of social housing and public buildings renovation with renewable technologies;

- number of green infrastructures realized in urban areas. 
In 2017, Italy drafted the Strategia Nazionale per lo Sviluppo Sostenibile (SNSvS) on the sustainability theme [17].

The topic of climate has been deepened in the choice $I V$. Decarbonize the economy, that gives objectives that can be assumed as targets:

- IV.2 Increasing sustainable mobility of people and goods;

- IV.3 Breaking down greenhouse gas emissions in nonETS sectors.

About the sustainable mobility of people and goods, an indicator is: 7.3 Double the overall rate of energy efficiency improvement by 2030.

About emissions, in the goal sustainable cities and communities, the following indicators are considered:

- Exposure of the urban population to particulate air pollution $<2.5 \mu \mathrm{m}$;

- Exposure of the urban population to particulate air pollution $<10 \mu m$;

- Exceedances of the daily limit value envisaged for PM10 in the provincial capital municipalities.

In Italy, associations have developed important awarenessraising, information and training initiatives on the climate theme, for the reduction of greenhouse gas emissions starting from the objectives assumed at international level with the Kyoto Protocol and the Paris Agreement, and with decisions at EU level.

Legambiente, in addition to a great ten-year work, in the 2019 Report Il clima è già cambiato [18], has collected and mapped information on damage caused by climatic phenomena, with the aim of planning and optimizing interventions. At the heart of the Report are urban areas and the impact of climate change on them. Cities are the areas most at risk for the consequences of climate change, because that is where most of the population lives. The Report proposes good practices such as climate adaptation plans, strategies and guidelines, already in place in European and Italian cities such as Glasgow, Bologna, and Padova.

Kyoto Club, in the Rapporto Mobilitaria 2019, Politiche di mobilità e qualità dell'aria nelle 14 città e aree metropolitane 2017-2018, in the light of an overall picture on the trend of air quality and policies in metropolitan cities, outlines a set of proposals for sustainable mobility, road safety and the decarbonisation of transport, in terms of strategic intervention tools and actions and measures to be implemented [19].

Calabria Region is developing specific activities in line with the UN, EU and Italian State for sustainable development.

Sustainable development is a central theme for the Economy and Finance Document of Calabria Region 20192021 (EFDR) [20] and the Regional Transportation Plan (RTP) published in 2016 [21]. In particular, RTP defines a vision and four goals, the sustainability is one of them.

About the city logistics, in the objective Urban Areas, there is the target (action) infrastructure and services enhancement in urban areas and a specific measure for 2.5 city logistics. It can be assumed that the related indicators are:

- the extension of urban areas addressed for pedestrianization, ZTL, green zones, low emission zones, cycle paths and metropolitan systems;

- daily $\mathrm{CO}_{2}$ emission of the generic mode of transport;

- number of plans elaborate/approved by Municipalities and Metropolitan Cities for monitoring measures aimed at sustainable development.
In Figure 1 there is a synthetic scheme of the main strategic documents at international, European, national and regional level produced by public actors. At each level, the main targets and indicator related to sustainability are reported.

It can be noted that there are not specific financial programs that link strategic goals to operative results. The lack is greater because the final decision maker are cities and town but don't have specific grants, with administrative and technical guidelines. In this empty between strategies and real implementation, the Calabria Region construct a bridge: firstly, defining the region role and then designing a political, technical and administrative path to obtain the results.

\begin{tabular}{|c|c|}
\hline INTERNATIONAL & EUROPEAN \\
\hline $\begin{array}{l}\text { United } \\
\text { Nation } \\
\end{array}$ & $\begin{array}{c}\text { European } \\
\text { Commission } \\
\end{array}$ \\
\hline $\begin{array}{c}\text { Agenda } 2030 \\
(2015)\end{array}$ & $\begin{array}{l}\text { Country Report Italy } \\
\text { (2019) }\end{array}$ \\
\hline $\begin{array}{l}\text { By } 2030 \text {, reduce the adverse per capita } \\
\text { environmental impact of cities }\end{array}$ & $\begin{array}{l}\text { - Promote energy efficiency and } \\
\text { the renewable energies } \\
\text { - Adaptation to climate change }\end{array}$ \\
\hline $\begin{array}{l}\text { Annual mean levels of } \\
\text { fine particulate matter in cities }\end{array}$ & $\begin{array}{c}\text { - Number of social housing and public } \\
\text { buildings renovation } \\
\text {-Number of green infrastructures } \\
\text { in urban areas }\end{array}$ \\
\hline NATIONAL & REGIONAL \\
\hline $\begin{array}{c}\text { Italian } \\
\text { government }\end{array}$ & $\begin{array}{c}\text { Calabrian } \\
\text { government }\end{array}$ \\
\hline $\begin{array}{c}\text { Strategia Nazionale Sviluppo Sostenibile } \\
(2017)\end{array}$ & $\begin{array}{l}\text { EFDR-RTP } \\
(2019-2021)\end{array}$ \\
\hline $\begin{array}{l}\text { - Increasing sustainable mobility } \\
\text {-Breaking down greenhouse ù } \\
\text { gas emissions }\end{array}$ & $\begin{array}{l}\text { Infrastructure and services } \\
\text { enhancement in urban areas }\end{array}$ \\
\hline $\begin{array}{c}\text { Double the overall rate of } \\
\text { energy efficiency improvement by } 2030 \\
\text { Exposure of the urban population } \\
\text { to particulate air pollution }\end{array}$ & $\begin{array}{l}\text {-Pedestrianization, ZTL, green zones, } \\
\text { •Low emission zones, cycle paths,.. } \\
\text { •Daily CO2 emission } \\
\text { •Number of plans elaborate/approved }\end{array}$ \\
\hline
\end{tabular}

Figure 1. Public actors, main strategic documents, targets and indicators

\section{ROLE OF REGION: TOP DOWNPLANNING PROCESS}

\subsection{Financial and scientific support}

Local and regional governments have a key role, but very different, to play and can make a decisive contribution to the implementation of global agreements.

They are called upon to pursue the sustainability objectives deriving from the 2030 Agenda for Sustainable Development and the United Nations Framework Convention on Climate Change (UNFCCC).

To pursue the sustainable development, it is necessary to implement actions to reach the great sustainability target from global to local level, as policies, strategies and programs.

For this purpose, the regional government can give a decisive supporting to the decision maker that can be only the local government (cities). The role of the regional administration is only of moral suasion that can be inserted along the three interconnected processes that involve the local administration, identified schematically as in Figure 2: 
- $\quad$ sustainable planning theories and international vision, that are studies to identify the vision and missions perspective for the city;

- regional rules, that are regulations and laws, books, guidelines and operative documents;

- city implementation development that is real city logistics development.

There are circular connections among planning theories and international vision, rules and implementation development; the smart city is a possible convergence [22]. To achieve this convergence, two ways are possible: first, the sustainable planning theories and international vision are pushed by decision makers into regional rules to address city implementation development; second, city implementation development influences regional rules from which sustainable planning theories and international vision [23].

These circular connections have been specified for the regional administration of Calabria, but can be adapted for any other planning problem where there are decision makers in subordinate relationships, as EU and State, State and Region.

In this paper the role of regional administration in assisting cities in the link from planning theories to rules is investigated. In this case, the regional administration can give financial resources, scientific and technical support in a collaborative approach with city decision maker and society, asking also a PE. In this way, the regional administration works in a topdown direction to local administration, but asks constraints to be respected, and realizes PE to guarantee the control in a bottom up direction.

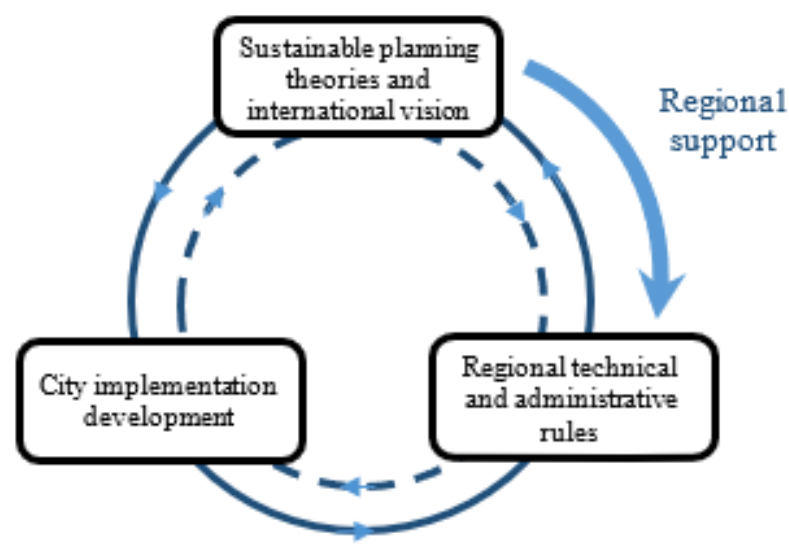

Figure 2. Circular connections (elaboration from source:[23])

Calabria, achieving international, European and national targets, through planning tools, such as the RTP and the EFDR, is an exemplary case of best practices. It is promoting and supporting to city logistics rules for city implementation development [14]. For this reason, the regional administration has developed processes of programming and implementation carried out by regional offices. The process of programming is aimed at defining the Implementation Program to indicate city logistics measures and their realization procedures. Implementation process is aimed at defining the Calls to finance design and realization of city logistics projects [24].

\subsection{Regional transportation plan}

The Calabria Region wants to pursue the sustainability targets to bring Calabria among the best regional examples of Europe by improving the livability of urban centers even with an efficient freight distribution, projecting itself towards the policy objectives of the new European programming ' 21 -'27 [16].

Since 2016, the regional urban mobility policies have been aimed at supporting local administrations in preparing urban plans. Transport is essential in the development of the urban center and it is linked with spatial and economic development.

Regional administration supports all interventions that are inspired and related to the APUM [25, 26], in particular to action 19 - Urban Freight Transport ad to the guidelines of PUM (Piani Urbani della Mobilità), SUMP (Sustainable Urban Mobility Plan) in EU and then PUMS (Piano Urbano di Mobiltà Sostenibile) in Italy [27-30].

The regional administration has implemented a technical and administrative path for city logistics that is consistent with a circular way described above [24]. Regional administration pushes the planning theory and international vision into regional rules and addressing city implementation development.

It has created a way for city logistics by planning, programming and implementation of the interventions, and giving to cities their realization [23, 30-32].

In 2016, Calabria approved RTP having a positively evaluation by regional department of environmental and territorial protection, and a positively evaluation by the EU Commission [21].

RTP supports the policies in transport and logistics system of Calabria in the medium and long term. His general vision is specified by four goals:

- $\quad$ regional economic development $(\mathrm{ED})$;

- external accessibility (EA);

- $\quad$ internal accessibility (IA);

- $\quad$ sustainability $(\mathrm{S})$.

To pursue this general vision, RTP defines ten strategic objectives. To each objective corresponds a strategic action and to each strategic action corresponds ten operational measures, which affect one or more goals of the vision.

The Objective 2 Urban areas indicates Action 2 Measures for infrastructure upgrading and services in urban areasthat comprises Measure 2.5 City Logistics.

The incidence of Measure 2.5 on goals of RTP's vision is on ED, IA and S. The interventions expected are reported in Table 1.

PUMS guidelines provides indications to simulate and evaluate the scenarios and monitor the plan. Indicators of achievement are indicated to evaluate the execution of the action or intervention, and related indicators

They are indications and not obligations to be respected. Indeed, in different sectors there are established regulations that allow to design and realize interventions. This is the case, for example, of the constructions sector. The Eurocodes (EC) are the European standards for design, to which the national regulations are aligned, in order to allow the designer to use common calculation criteria [33].

In Italy, the TSC (Norme Tecniche per le Costruzioni - NTC 2018) acquire Eurocodes and set the regulations for civil and industrial buildings and bridges, for geotechnical and seismic design and for testing, and for all other related elements [34].

In the case under consideration, on the contrary, there are no planning regulations. But there are mathematical models in order to allow the planner to decide by simulating the results of the interventions considered. 
Table 1. Interventions

\begin{tabular}{cl}
\hline Type & \multicolumn{1}{c}{ Details } \\
\hline Supply & - time windows \\
management & - vehicle dimension constraints \\
& - use of preferential lanes for local public transport \\
& - accesses with a Nearby Delivery Area network \\
& (NDA) \\
& - integration with long-distance intermodal transport \\
& with Urban Distribution Centre (UDC) \\
\hline Demand & - support to urban policies to promote innovative \\
management & models on cooperation and on local public and \\
& private partnerships \\
& - rationalization of distribution, with the \\
& maximization of loads per vehicle and the \\
& minimization of total vehicles \\
\hline Infrastructures & - delivery area network (including booking) within \\
& LTZ \\
& - UDC and NDA \\
& - Pick-up Point to support the new online purchase \\
& models (e-commerce) \\
\hline ICT and ITS & - app or services on existing telematics networks \\
& - traffic management and control \\
- (including delivery area booking)
\end{tabular}

In urban strategic planning an input-output model to capture the relationship between spatial economic and transport systems at national and urban scales is proposed [35].

In urban freight transport planning, in particular, a demand model allows to associate to an activity and supy system the average value of the demand flow, in a time period, with its relevant characteristics:

$$
Q_{o d}(K 1, K 2, \ldots)=Q(S E, T, \beta)
$$

where, $Q_{o d}(K 1, K 2, \ldots)$ is the average flow of goods between the general zones $o$ and $d$ with characteristics $K 1$, $K 2$,... associated with the product category, the sector of economic activity, the type of retailer, the type of service; $S E$ is the vector of socio-economic variables associated with production and consumption; $T$ is the vector of variables of the transport system related to the attributes of the different transport modes; $\beta$ is the vector of the coefficients present in the model.

A modelling system to simulate goods movements at urban scale is proposed as a combination of two levels [36]:

- commodity level, to analyze the flows in terms of quantity,

- $\quad$ vehicle level, to convert quantity flows in vehicle flows. Commodity level can be formalized:

$$
Q_{o d}^{H}[s]=Q_{. d}^{H}[s] \cdot p^{H}[o / d s]
$$

where, $Q_{o d}^{H}[s]$ is the average flow of quantity of goods of type $s$ between zones $o$ and $d$, in the period $H ; Q_{. d}^{H}[s]$ is attraction model and calculates the quantity of goods of type $s$ attracted by zone $d$ in $H ; p^{H}[o / d s]$ is acquisition model and calculates the probability that goods of type $s$, attracted by zone $d$, arrive from zone $o$.

Vehicle level can be formalized:

$$
V C_{o, d}^{i H}[s, m]=\frac{Q_{o d}^{H}[s] \cdot p[m / o d s] \cdot p[i / m o d s]}{q_{s m}^{i}}
$$

where, $V C_{o, d}^{i H}[s, m]$ is the average flow of commercial vehicles of type $i$, which transports goods of type $s$ between zones $o$ and $d$ in $H$ with the type of service $m ; p[m / o d s]$ is the service model and calculates the probability that the goods of the type $s$, attracted by the zone $d$, arrive from the zone $o$ and are distributed with the type of servicem; $p[i / \operatorname{mods}]$ is the whole model and calculates the probability that the goods of the type $s$, attracted by the zone $d$, arrive from the zone $o$, are distributed with the type of service $m$ and the type of vehicle $i$; $q_{s m}^{i}$ is the quantity of goods of the type $s$, delivered with the type of service $m$ and the type of vehicle $i$.

This model simulates the flow of goods (demand) with the relevant characteristics starting from the overall demand for goods attracted by each destination in $H\left(Q_{o d}^{H}[s]\right)$, and divides it among the origins, the types of services and vehicles.

It is to be noted that this model represents the integration of commodity consumers and commodity suppliers/shippers/retailers, respect to the segments of mobility of shopping (consumers) and restocking (suppliers/shippers/retailers).

\subsection{City logistics measures}

After the RTP approval, the circular way has involved from sustainable planning theories and international vision to regional rules by two sub processes:

- programming;

- implementation.

The programming is aimed at elaborating the Implementation Program on Measure 2.5 City logistics to [37]:

- $\quad$ specify RTP vision on city logistics;

- reconstruct documentary framework of plans and projects in the world, Europe, Italy and Calabria;

- define city logistics area, city requirements, fundable interventions, minimum level of project, minimum life of the intervention, costs;

- indicate operational specifications for evaluation and financing.

In particular, city logistics area is defined as an area where the interventions are applied.

The city requirements are related to the inhabitants; to submit a proposal, the city must have:

- more than 30,000 inhabitants, or

- less than 30,000 and Limited Traffic Zone (LTZ).

The implementation is aimed at building a tool to finance design and realize of city logistics projects. Two Calls have been opened according to Implementation Program.

The first Call was opened on September 2018 [38], the second on September 2019 [39].

The Calls indicate the criteria to projects evaluation that depend on the results modelled and estimated respect to requests from the regional administration. The aim is to give a score to each proposal and to make a ranking to assign the financing. The maximum score is 100 obtained from the sum in three categories of criteria: reduction of pollution (maximum 60), increase in distribution efficiency (maximum 20 ), sustainability of the project (maximum 20).

It is noted that each city makes a self-assessment to assigns itself a score, which is the basis for the successive control and evaluation by the regional technical sector. 
At the first Call, six cities have submitted a project and three have been funded: Rende in North, Vibo in the Center and Reggio Calabria in the South [38]. They are with more than 30,000 inhabitants, which for Calabria can be considered cities: Reggio is the largest in Calabria with more than 180,000. The projects are characterized by a high level of quality and include time windows differentiated by type of vehicle (load, engine, environmental performance), ICT/ITS, fleets ecofriendly and innovative, CDU and NDA.

At the second Call, seven cities and towns have submitted a project and six have been funded: Corigliano Rossano, Paola, Fiumefreddo in North, Catanzaro, Pizzo e Tropea in the Center. Corigliano Rossano and Catanzaro are with more than 30,000 inhabitants, Paola, Fiumefreddo, Pizzo e Tropea are with less than 30,000 inhabitants but have an LTZ [40]. Moreover, this second group of towns has relevant tourist flows that influence the freight distribution, as quantities required, especially in the summer.

\section{ROLE OF REGION: BOTTOM UPPUBLIC ENGAGEMENTPROCESS}

\subsection{Public engagement to push people participation}

The top down processes have been accompanied by a bottom up process performed by PE with several training activities to support cities and towns involved in city logistics projects and to improve capability of stakeholders [41].

Regional administration has promoted the PE that, as it is little known, can take various forms, likes the ones explained in this work.

PE has been activated by the regional administration of Calabria to participate and share the choices for the regional transport and logistics system until the approval of the RTP. The aim has been the participation of all the stakeholders involved in the planning processes through the construction of shared objectives by a bottom-up approach. Indeed, the involvement of all stakeholders is intended as the way to the success of the initiatives, because the wider participation of the parties can contribute with its proposals to achieve shared results.

The PE has involved environmental stakeholders and others as citizens, associations and universities, in events to the present and participate planning process of RTP and to web publications starting to approval of the planning methodology in January 2016. The first event with the greatest involvement of stakeholders has been in May 2016 in Catanzaro. Many other events have also been organized in other locations of Calabria up to final approval in December 2016.

Regional administration believes that the PE [42], properly specified, is a tool to share decisions with local administrations and to support them in the bridge from regional rules to city development. The aim is to quicken the implementation of SUMP, including city logistics. In the same time, regional administration can introduce the PE as a constraint for the local administration. This is way to make local administration the final decision maker, when instead the regional administration plays a promoter role.

For the National Co-ordinating Centre for Public Engagement (NCCPE) Public engagement describes the myriad of ways in which the activity and benefits of higher education and research can be shared with the public. Engagement is by definition a two-way process, involving interaction and listening, with the goal of generating mutual benefit [43].

Mutual benefits are developing new skills, gaining new insights or ideas, developing better research, raising aspiration, or being inspired. Public engagement is multi-faceted. It can include outreach, collaborative research, citizen science, lifelong learning, community engagement, and engagement with partners.

In addition, universities engage through community based learning, widening participation, corporate social responsibility, etc.

The reasons of $\mathrm{PE}$ are different but when the common information on a specific process as city logistics are very few, there is a first reason that is to better connect the work of universities and research institutes with collectivity.

NCCPE considers four principles that make high quality engagement [43]:

- $\quad$ purpose, to identify the reason of public engagement;

- people, to choose who is involved in the project;

- $\quad$ process, to understand how the purpose are appropriate to the people;

- evaluation, to establish the value.

In particular, the process consists in a set of categories of activity. These categories of activity are broad and can be used in different contexts, for different purposes and with different groups of people, in informal and formal ways, over short and long timescales, and combining them together.

The categories of activity:

- lecture/presentation, as writing, performance, workshop, collaboration, citizen research;

- broadcast, as encounter, exhibition, network, consultation, collaborative research;

- event, as websites, exhibit, social media, formal learning, enquiry service.

The practical implementation of PE is known for the standard approach of an evaluation and judge on civil project. Very new is the implementation of a program and even more if the argument is not common. For this last case and its role, regional administration of Calabria implemented a structured approach deriving from the one developed by the USA Department of Homeland Security (DHS).

The DHS Science and Technology Directorate (S\&T) works with DHS operational components to engage involved personnel to deliver solutions for the homeland security mission and to increase their capability. By DHS, the capability is a characteristic derived from a combination of: properly planned, organized, equipped, trained, and exercised personnel who achieve the intended outcome.

In particular, in DHS, Federal Emergency Management Agency (FEMA) has made National Exercise Program (NEP) that is a national initiative to test, assess and improve the nation's preparedness and resiliency.

NEP is a two-year cycle of two categories of exercises across the nation that examine and validate capabilities in all preparedness mission areas [44].

The NEP is consistent with the Homeland Security Exercise and Evaluation Program (HSEEP) methodology [45, 46].

These categories of exercises can be:

- discussion-based, seminars, workshops, tabletop exercises, games:

- operations-based, drills, functional exercises, fullscale exercises.

A set of training activities of increasing complexity are reported in Figure 3. 


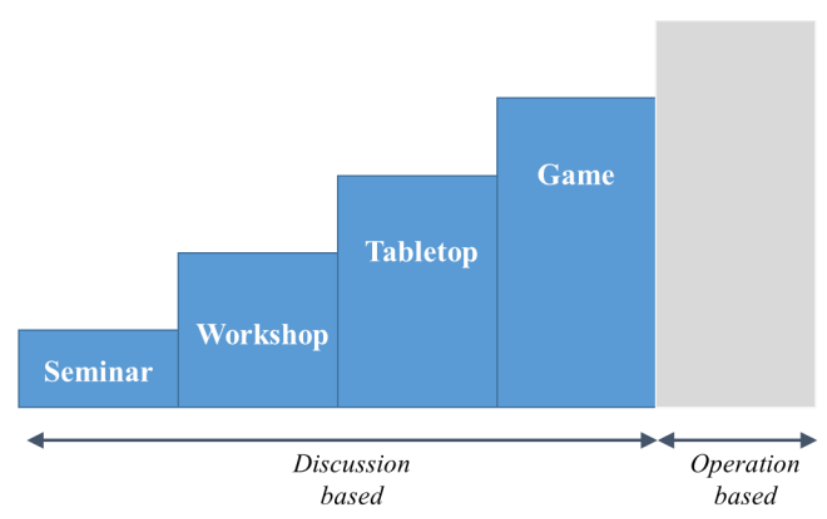

Figure 3. Type of exercises (evolved source: [30])

\subsection{Public engagement to construct collective knowledge}

The PE has been developed before and after the Calls publications. Before to specify and calibrate scientific theories on urban freight transport for calabrian cities. After to present the most advanced international experiences.

In city logistics path, regional administration supported local administration with PE by training activities like those of USA HSEEP recalled in 4.1 [41].

PE has been finalized to developing new skills, gaining new insights or ideas, raising aspiration, or being inspired, outreach on sustainability items, and to create a collaborative circle among all the partner [47].

In Calabria, PE allows the important result of supporting local administrations and allows those who had minimal knowledge in city logistics to go up and carry out quality projects.

Considering that in Calabria no city has ever been activated to acquire city logistics policies, the first attention was paid to the increase technical and administrative knowledge and skills.

The involvement and the presence of universities and the national and international researchers among the discussants has allowed dissemination of the best and most recent developments in scientific research on city logistics.

According to NCCPE principles that make high quality of $\mathrm{PE}$, the purposes have been identified, the people to be involved were chosen, and the process has been planned by activities appropriated for purpose and people.

These activities have been developed in a mixed form by discussion based exercises, in informal or formal ways, according to HSEEP, and by events as website and e-mail (logisticaurbana@regione.calabria.it) according NCCPE. It can be noted that some activities are indicated by both HSEEP and NCCPE, as workshop.

Discussion based exercises are based on verbal comparison and they include exercises with increasing complexity from seminars, workshops, tabletops and games.

E-mail has been a tool to accompany the local administration with a direct channel to guarantee participation and dialogue and promote inclusion logic social, information sharing, process monitoring and exchange of good practices.

All the activities are provided the necessary information and documentation to assist all cities involved in projects.

Moreover, these activities are improved capability of partners such as authorities, public employees and managers, transport planning experts and researchers, associations on city logistics.

The people involved were selected based on a potential profile of knowledge and skills that had to be consistent with the purpose of the PE for a specific aspect of city logistics, to guide and maximize the effectiveness of the evaluation.

The process has been developed in programming to obtain Implementation Program, and in implementation to build both Calls according to a program of events (Table 2).

Table 2. Program of main PE events

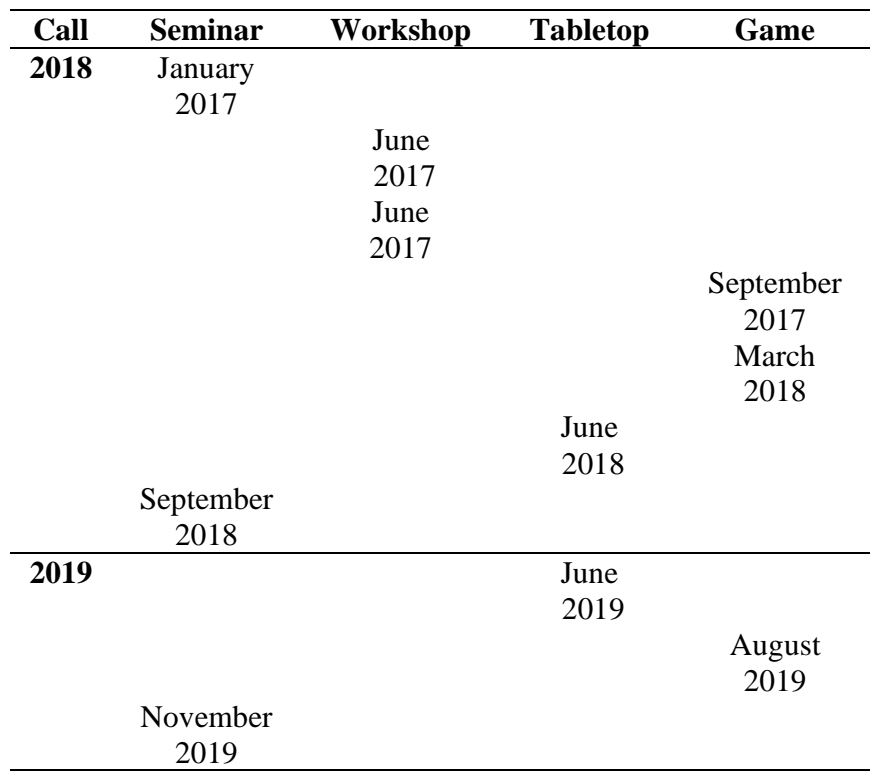

\subsubsection{Seminar}

A seminar is an informal discussion to inform people on new documents that are developing or on major changes to existing plans or procedures.

Seminars were held in programming and implementation.

In programming, the purpose of seminar in January 2017 was to inform participants to general project of RTP and its measures, in particular City logistics, and the related planning procedures; it was useful to discuss on developing to RTP.

The people involved are regional authorities, managers, employees and experts on transport planning.

In implementation, the purpose of the seminars was to inform participants on procedures of Calls after their opening: in September 2018 and in November 2019. They have been useful to discuss on developing the procedure to submit the projects.

\subsubsection{Workshop}

A workshop is an informal discussion where the participants interact to build a product, such as a draft plan or program.

Workshops were held in programming and implementation.

In programming, the purpose of first workshop in June 2017 was on effects of urban freight distribution on environment, as congestion, air pollution, noise [47]. The purpose of second workshop in July 2017 was on effects of urban freight distribution, as well as on the environment, on economy, as logistic costs and price of products, and society, as risk of accidents due to a combination of different types of vehicles on the road [48-51]. In both workshops, participants interacted on all aspects of freight distribution, but the discussion was different due to their different skills.

\subsubsection{Tabletop}

A tabletop is an informal discussion that involves key personnel discussing on hypothetical scenarios. The participants interact and are encouraged to analyze and solve 
a problem collaboratively.

In implementation, the purpose of first tabletop in June 2018 was on the strategic results, such as reduction of atmospheric and acoustic pollution, reduction of accidents, improvement of accessibility and efficiency of the freight distribution flows with advantages both for citizens and couriers. The tabletop happened before the opening of the first Call and it was useful to discuss on developing of the possible measures to realize in the cities, considering benefits and costs of city logistics projects. The tabletop has been developed because it needs to be calibrated on the specific urban areas of Calabria and to involve key personnel discussing hypothetical scenarios respect to city logistics problems. It was useful for enhance general awareness and to discuss issues in depth, collaboratively examining based on the latest scientific research also. In this tabletop, city representatives collaborated by responding in real time to a questionnaire on the characteristics of their cities related to the organization of traffic, such as the presence of LTZ, pedestrian areas, and the distribution network, such as shops, couriers.

Their responses were useful for the construction of the calibrated Call for Calabria.

The purpose of second tabletop in June 2019 was on the strategic results respect to the latest scientific research at national and international level. The tabletop happened after the selection of funded projects by the first Call, and it was useful to discuss on developing of the measures that will be realized in the cities considering benefits and costs of city logistics projects. In this tabletop, city representatives collaborated by the explanation of their projects and how they will be realized. These reports of the real case were useful for the construction of second Call. The tabletop has been opened to all the cities that presume to participate at the second Call.

Moreover, during the opening of the Calls, others tabletops were developed: one day a week, the regional experts of transport provided technical support to local technicians to organize a city logistics proposal.

\subsubsection{Game}

A game is a simulation of operations designed to estimate the results of an actual or hypothetical scenario; it is a useful tool to validate plans or evaluate resources.

Games were held in implementation.

The purpose of the game in September 2017 was to simulate a test case related to a generic urban area. The game has been happened before the opening of the Call and it has been useful to simulate a possible scenario of measures implementation and the related results.

The game was played considering the formulation of the model proposed in 3.2 to simulate the demand of goods starting to a simplified test case with a territorial system with 4 traffic zones, 4 centroids connected to the road network and 2 type of goods.

The proposed system of models is derived from literature $[11,36]$ as the evaluation methods [52].

A gravitational model can be used to estimate the acquisition zone. The variables are the number of wholesalers and the generalized travel costs of the minimum path and related parameters are defined. It is assumed that restocking cannot take place in the same acquisition zone. It is assumed that the restocking is as one-to-one and that for each good there is only one vehicle that delivers the quantity $q_{s m}^{i}$.

To estimate attraction model, it is possible to calculate the quantity of goods of type $s$ attracted by zone $d$ as:

$$
Q_{. d}^{H}[s]=n_{d}[s] \cdot m^{H}[s]
$$

where, $n_{d}[s]$ is the number of retailers for goods $s$ and $m^{H}[s]$ is an index of daily attraction.

It is possible to do other simplifications. Indeed, in practice, having determined the quantity of goods $s$ between $o$ and d, with the type of servicem (one-to-one), only one type of vehicle $i$ is identified that, on average, carries out this type of journey to which an average quantity transported is assigned (about $400 \mathrm{~kg}$ for fruit and vegetable, $70 \mathrm{~kg}$ for bread). Therefore, $p[\mathrm{~m} / \mathrm{ods}]$ and $p[i / \operatorname{mods}]$ are equal to 1 .

The number of vehicles $i$ transporting the goods $s$ between $o$ and $d$ zones with service $m$ in $H$-day results:

$$
V C_{o, d}^{i H}[s, m]=\frac{Q_{o d}^{H}[s]}{q_{s m}^{i}}
$$

Table 3 shows an example of demand matrix obtained: the number of vehicles simulated per type of goods is indicated for each $o / d$ zones.

\begin{tabular}{|c|c|c|c|c|c|c|}
\hline $\mathbf{S}$ & o/d & 1 & 2 & 3 & 4 & Total \\
\hline \multirow{4}{*}{ 昰 } & 1 & 0 & 28 & 22 & 25 & 75 \\
\hline & 2 & 11 & 0 & 30 & 27 & 68 \\
\hline & 3 & 9 & 15 & 0 & 43 & 66 \\
\hline & 4 & 11 & 17 & 35 & 0 & 63 \\
\hline \multirow{5}{*}{ : } & 1 & 0 & 30 & 31 & 16 & 77 \\
\hline & 2 & 12 & 0 & 46 & 18 & 76 \\
\hline & 3 & 10 & 15 & 0 & 29 & 54 \\
\hline & 4 & 12 & 18 & 49 & 0 & 79 \\
\hline & & 64 & 123 & 212 & 158 & 557 \\
\hline
\end{tabular}

Table 3. Vehicles demand od matrix

When the number of vehicles is known, the effects of city logistics measures can be analyzed, for example with respect to the time windows, the CDU and NDA realization or/and the ICT/ITS applications. It is possible to estimate the reduction of $\mathrm{CO}$ by models for calculating vehicular traffic emissions, but also the vehicle $\mathrm{km}$ and the number of deliveries respect to expected scenario for the optimization of distribution.

The purpose of the game in March 2018 was to update the results of a first game by georeferential methods and the latest scientific research.

The purpose of the game in August 2019 was to simulate a test case respect to the obligatory interventions foreseen by the second Call, not included in the first.

These measures include ITS to control and dynamically manage access (monitoring) and loading /unloading zones in city logistics areas. The implementation tries to give a central role to the operators as protagonists of the efficiency of the distribution with the optimization of deliveries. At the same time, the dynamic management of loading / unloading zones using ITS was intended as a tool to size their number and contain the consumption of public land to be allocated to delivery vehicles. The possibility of managing of these zones in real time makes it possible to optimize occupancy times, minimizing the time in which they are free and the waiting time to occupy them, with the same number of incoming vehicles in controlled areas.

The game is based on a simplified hypothesis: there are 557 freight vehicles to shops restocking every day, as in a game in previous game.

It is assumed that the measure applied is time windows and 
allows delivering only 3 hours a day, as required by the Implementation Program for vehicles up to 3.5 tons more polluting.

It is also assumed that each vehicle makes 3 deliveries per day, so the total deliveries are 1671 .

If the average time of loading / unloading is 15 minutes, as indicated by cities in tabletop in June 2018, in 3 hours there are 12 slots available and the necessary loading / unloading zones are 140. This is the estimated minimum level, but represents an indication for local administration considering that there are no rules in this regard also.

\section{CONCLUSIONS}

The Calabria Region has the sustainable development among its main objectives; therefore, it has promoted appropriate activities in the fields in which it can operate directly.

The most important programs concern the development of public transport for people; the strengthening and renewal of fleets of public transport vehicles and a first specific programs related to urban freight transport. The role of the Region is different relatively to the two specific programs. While for the local public transport an agreement and an intense collaboration between the Region and local administration is necessary, for the urban freight distribution local administration is the only one responsible, and the Region can perform an accompany to it. To this end, Calabria wanted to orient and support towards of development of sustainability.

For urban logistics, the objective is to reduce $\mathrm{CO}_{2}$ emissions in a general framework aimed at raising the level of city livability and, in the same time, it increasing the efficiency of distribution.

The paper answers the questions asked.

It's possible to acquire international and national documents and related indicators and target to orient local administrations, and to realize an innovative integrated process of collaboration between different administrations to success of initiatives.

It's possible to give rules to simulate urban freight transport by a mathematical model, when there are no mandatory rules, as for the construction sector, and realize a top down process.

It's possible help cities in a way for city logistics by a public engagement and realize bottom up process to obtain shared results.

For this, the regional administration has carried out an overall technical and administrative path with the definition and implementation of the planning, programming and implementation processes at the regional scale, while the management is the responsibility of the local administration. The aim is to push local administrations to implement effective urban logistics according to RTP Measure 2.5 City logistics, and to the indications of APUM [25][26] and SUMPs [28][29].

The Region planned the City logistics with the RTP, then approved the Implementation Program and published two Calls for the granting of financing and the realization of urban logistics projects in Calabria.

The next phase is the monitoring of output, outcome and obtained goals in the cities.

The Region has supported local administration by public engagement for participation and sharing of the choices of the Region, which evolves with the control of the projects.

\section{ACKNOWLEDGMENT}

This paper is based on the work done by the authors at the regional administration of Calabria from 2016 to 2019. The authors worked on the preparation of the RTP and on the implementation of his measures, such as City logistics. They collaborated, in various roles, with the regional government and the human resources of regional technical office.

\section{REFERENCES}

[1] WCED - World Commission on Environment and Development. (1987). Report of the World Commission on Environment and Development: Our Common Future. https://sustainabledevelopment.un.org/content/documen ts/5987our-common-future.pdf.

[2] United Nations. (2015). Global indicator framework for the Sustainable Development Goals and targets of the 2030 Agenda for Sustainable Development. https://unstats.un.org/sdgs/indicators/Global\%20Indicat or\%20Framework\%20after\%20refinement_Eng.pdf.

[3] United Nations Framework Convention on Climate Change. (2015). Paris Agreement. https://unfccc.int/.

[4] European Commission. (2011). White paper 2011. Roadmap to a Single European Transport Area - Towards a competitive and resource efficient transport system. COM (2011) 144 final.

[5] Browne, M., Allen, J., Alexander, P. (2016). Business improvement districts in urban freight sustainability initiatives: A case study approach. Transportation Research Procedia, 12: 450-460. https://doi.org/10.1016/j.trpro.2016.02.079

[6] Taniguchi, E., Thompson, R. (2018, eds.). City Logistics 3 - Towards Sustainable and Liveable Cities. WileyISTE.

[7] Russo, F., Comi, A. (2020). Investigating the effects of city logistics measures on the economy of the city. Sustainability, 12(4): https://doi.org/10.3390/su12041439

[8] BESTUFS (2007). BESTUFS - Good Practice Guide on Urban Freight. Available online: http:// www.bestufs.net.

[9] Visser, J., Nemoto, T., Browne, M. (2013). Home delivery and the impacts on urban freight transport: A review. 8th International Conference on City Logistics. Procedia - Social and behavorial Sciences, 125: 15-27. https://doi.org/10.1016/j.sbspro.2014.01.1452

[10] Ducret, R. (2014). Parcel deliveries and urban logistics: Changes and challenges in the courier express and parcel sector in Europe-The French case. Research in Transportation Business Management, 11: 15-22. https://doi.org/10.1016/j.rtbm.2014.06.009

[11] Russo, F. (2013). Modeling Behavioral Aspects of Urban Freight Movement. In: Ben-Akiva, M., Meersman, H. and Van de Voorde, E. (Ed.), Freight Transport Modelling, Emerald Group Publishing Limited, Bingley, U.K., 353-375. https://doi.org/10.1108/9781781902868018

[12] Baur, A.H., Thess, M., Kleinschmit, B., Creutzig, F. (2014). Urban climate change mitigation in Europe: looking at and beyond the role of population density. Journal of Urban Planning and Development, 140(1). https://doi.org/10.1061/(ASCE)UP.1943-5444.0000165

[13] Holguín-Verasa, J., Lealb, J.A, Sánchez-Diazc, I., 
Browned, M., Wojtowicza J. (2020). State of the art and practice of urban freight management: Part I: Infrastructure, vehicle-related, and traffic operations. Transportation Research Part A: Policy and Practice, 137: 360-382. https://doi.org/10.1016/j.tra.2018.10.037

[14] Russo, F., Pellicanò, D.S. (2019). Planning and sustainable development of urban logistics: from international goals to regional realization. WIT Transactions on Ecology and the Environment, 238: 5972. https://doi.org/10.2495/SC190061

[15] United Nations. (2015). Transforming our world: the 2030 Agenda for Sustainable Development.https://sustainabledevelopment.un.org/con tent/documents/21252030\%20Agenda $\% 20$ for $\% 20$ Sustai nable\%20Development\%20web.pdf.

[16] European Commission. (2019). Commission Staff Working Document. Country Report Italy 2019. https://ec.europa.eu/info/sites/info/files/file_import/201 9-european-semester-country-report-italy_en.pdf.

[17] MATTM, Ministero dell'Ambiente e della Tutela del Territorio e del Mare. (2017). Strategia Nazionale per lo Sviluppo Sostenibile. https://www.minambiente.it/sites/default/files/archivio_ immagini/Galletti/Comunicati/snsvs_ottobre2017.pdf.

[18] Legambiente, (2019). Il clima è già cambiato. Rapporto 2019 dell'Osservatorio di Legambiente Climacittà. https://www.legambiente.it/wpcontent/uploads/2019/11/Il-Clima-è-già-cambiato2019.pdf.

[19] Donati, A., Petracchini, F. (a cura di) (2019). Mobilitaria 2019. Politiche di mobilità e qualità dell'aria nelle 14 città e aree metropolitane 2017-2018. $2^{\circ}$ Rapporto Kyoto Club - CNR-IIA in collaborazione con Opmus Isfort.

[20] Regione Calabria. (2017a). Documento di Economia e Finanza della Regione Calabria (DEFR).

[21] Regione Calabria. (2016). Piano Regionale dei Trasporti. http://portale.regione.calabria.it/website/organizzazione/ dipartimento6/subsite/pianoregionale/.

[22] Russo., F., Panuccio, P., Rindone, C. (2014). The process of smart city at an EU level. WIT Transaction on Ecology and Environment, 191: 979-989. https://doi.org/10.2495/SC140832

[23] Russo, F., Panuccio, P., Rindone, C. (2016). European plans for smart city: from theories and rules to logistics test case. European Planning Studies, 24(9): 1709-1726. https://doi.org/10.1080/09654313.2016.1182120

[24] Calabrò, T., Cozza d'Onofrio, M., Iiritano, G., Trecozzi, M.R. (2019a). Regional plan and program linked to EU policy for city logistics: The case of Calabria Region. WIT Transactions on the Built Environment, 188: 141152. https://doi.org/10.2495/CC190131

[25] European Commission (2009). Action Plan on urban mobility. COM (2009) 490https:/ec.europa.eu/transport/themes/urban/urban mobility/action_plan_en.

[26] European Commission (2013). Review of the Action Plan on Urban Mobility. Panteia. Research to progress. https:// ec.europa.eu/transport/sites/transport/files/ themes/urban/studies/doc/2013-07-review-of-theaction-plan-on-urban-mobility.pdf.

[27] Italy, Ministero dei Trasporti e della Navigazione (1999). I quaderni del Piano Generale dei trasporti.Linee guida per la redazione e la gestione dei Piani Urbani della Mobilità (PUM).
[28] Eltis. (2013). Guidelines Developing and Implementing a Sustainable Urban Mobility Plan. https://www.eltis.org/guidelines/sump-guidelines.

[29] Eltis. (2019). Guidelines for Developing and implementing a Sustainable urban mobility plan second edition. https://www.eltis.org/sites/default/files/sumpguidelines-2019_mediumres.pdf.

[30] Italy, Ministero delle Infrastrutture e dei Trasporti, (2017). Individuazione delle linee guida per i piani urbani di mobilità sostenibile, ai sensi dell'articolo 3, comma 7, del decreto legislativo 16 dicembre 2016, n. 257.

[31] Healey, P., Williams, R. (1993). European urban planning systems: Diversity and convergence. Urban Studies, 30(4/5): 701-720. https://doi.org/10.1080/00420989320081881

[32] Hall, P.G. (2002) Urban and Regional Planning. 4th edition, London: Routledge.

[33] EU, European Commission (2003), Commission Recommendation of 11 December 2003 on the implementation and use of Eurocodes for construction works and structural construction products (2003/887/CE).

[34] Italy, Ministero delle Infrastrutture e dei trasporti (2018). Decreto 17 maggio 2018, Aggiornamento delle «Norme tecniche per le costruzioni».

[35] Russo, F., Musolino, G. (2012). A unifying modelling framework to simulate the Spatial Economic Transport Interaction process at urban and national scales. Journal of Transport Geography, 24: 189-197. https://doi.org/10.1016/j.jtrangeo.2012.02.003

[36] Russo, F., Comi, A. (2010). A modelling system to simulate goods movements at an urban scale. Transportation, 37: 987-1009. https://doi.org/10.1007/s11116-010-9276-y

[37] Regione Calabria (2017b). Delibera di Giunta Regionale (DGR 391/2017), Programma di attuazione - Misura 2.5 City Logistics. https://portale.regione.calabria.it/website/portaltemplate s/view/view.cfm?4959.

[38] Regione Calabria (2018). Manifestazione di interesse. https://www.regione.calabria.it/website/portaltemplates/ view/view_bando.cfm?2998.

[39] Regione Calabria (2019). Manifestazione di interesse. https://www.regione.calabria.it/website/portaltemplates/ view/view_bando.cfm?2998.

[40] Regione Calabria (2020). Manifestazione di interesse. https://www.regione.calabria.it/website/portaltemplates/ view/view_bando.cfm?2998.

[41] Calabrò, T., Iiritano, G., Trecozzi, M.R. (2019b). Activities training on city logistics: case of Calabria region. WIT Transactions on Ecology and the Environment, 238: 161-171. https://doi.org/10.2495/SC190151

[42] Cascetta, E., Pagliara, F. (2013). Public engagement for planning and designing transportation systems. Science Direct, Procedia - Social and Behavioral Sciences, 87: 103-116. https://doi.org/10.1016/j.sbspro.2013.10.597

[43] NCCPE (2013) UK. www.publicengagement.ac.uk/about-engagement.

[44] FEMA (2019). National Exercise Program. https:/www.fema.gov/national-exercise-program.

[45] FEMA (2007). Homeland Security Exercise and Evaluation Program (HSEEP). https:// hseep.dhs.gov/ 
pages/ 1001_HSEEP7.aspx.

[46] FEMA (2013). Homeland Security Exercise and Evaluation Program (HSEEP) https://preptoolkit.fema.gov/documents/1269813/12698 61/HSEEP_Revision_Apr13_Final.pdf/65bc7843-1d1047b7-bc0d-45118a4d21da.

[47] Russo, F., Rindone, C., Trecozzi, M.R. (2012). The role of training in evacuation. WIT Transactions on Information and Communication Technologies, 44: 491502. https://doi.org/10.2495/RISK120411

[48] Taniguchi, E. (2014). Concepts of city logistics for sustainable and liveable cities. Procedia - Social and Behavioral Sciences, 151: 310-317. https://doi.org/10.1016/j.sbspro.2014.10.029

[49] Taniguchi, E., Fwa, T.F., Thompson, R.G. (2013). Urban
Transportation and Logistics: Health, Safety, and Security Concerns. Baca Raton, CRC Press. https://doi.org/10.1201/b16346

[50] Elvik, R., Vaa, T., Erke, A., Sorensen, M. (2009). The Handbook of Road Safety Measures. Emerald Group Publishing: Bingley, UK.

[51] Russo, F., Comi, A. (2017). From the analysis of European accident data to safety assessment for planning: the role of good vehicles in urban area. European Transport Research Review, 9(9): 1-12. https://doi.org/10.1007/s12544-017-0225-0

[52] Russo, F., Rindone, C. (2010). Evaluation methods of evacuating planning. WIT Transaction on Build Environment, 111: 335-343. https://doi.org/10.2495/UT100301 